報 文

\title{
マウスを用いた受身腹壁アナフィラキシー $(\mathrm{PAA})$ 反応の開発と 食品の抗アレルギー効果検索への応用
}

(平成 10 年 1 月 5 日受理)

$\begin{array}{lll}\text { 福井久恵*1 } & \text { 片岡裕美*1 } & \text { 扇間昌 規*1 } \\ & \text { 伊藤誉志男*1 } & \text { 高 垣 } \text { 裕 }^{* 2}\end{array}$

\section{Development of the Mouse Passive Abdominal Wall Anaphylaxis (PAA) Method and Application of the Method to Search for Anti-allergic Effect of Foods}

\author{
Hisae FukuI*1, Hiromi Kataoka*1, Masanori Semma*1, Yoshio Ito*1 \\ and Yutaka TAKAGAKI*2
(*1Faculty of Pharmaceutical Sciences, Mukogawa Women's University: 11-68, Koshien Kyuban-cho, Nishinomiya 663-8179, Japan; *2Osaka Prefectural Institute of
Public Health: 1-3-69, Nakamichi, Higashinari-ku, Osaka 537-0025, Japan)

Food allergy, which generally belongs to the category of Type I hypersensitivity reaction, is a serious health problem. Previously, we reported two types of mouse anaphylactic models, one using the abdominal wall as a site for both induction and estimation (AW method), and the other estimating the hypotension in mice sensitized passively with mouse monoclonal antiDNP IgE.

In this paper, we propose a passive abdominal wall anaphylaxis (PAA) method for use in screening for anti-allergic substances. Normal mice were intraperitoneally sensitized with mouse monoclonal anti-DNP IgE (5 $\mu \mathrm{g} /$ mouse) and 24 hours later, challenged with dinitrophenyl human serum albumin $(10 \mu \mathrm{g} / 50 \mu \mathrm{L} / \mathrm{site})$ on the abdominal wall. The PAA was estimated in terms of the increase of vascular permeability at the challenged abdominal wall site.

The PAA was inhibited by the oral preadministration of diphenhydramine in a dosedependent manner (PAA inhibition, PAAI). The anti-allergic activities of such well-known anti-allergic foods as oolong tea, garlic, and leek were confirmed by the PAAI test. Therefore, the PAA method appears to be applicable for the screening of anti-allergic substances in foods, simply, rapidly, and with high sensitivity.

(Received January 5, 1998)

Key words: 腹壁 abdominal wall; 受動感作 passive sensitization; 受身腹壁アナフィラキシー passive abdominal anaphylaxis; 食品抗アレルギー効果 food anti-allergic effect

緒言

現在，深刻な社会問題となっている疾患の 1 つに食 物アレルギーがある．食物アレルギーは食物成分をアレ

\footnotetext{
*1 武庫川女子大学薬学部： $\mathbf{T} 663-8179$ 兵庫県西宮市甲子 園九番町 11-68

*2 大阪府立公衆衛生研究所： $\mathbf{T} 537-0025$ 大阪市東成区中道 $1-3-69$
}

ルゲンとして引き起こされ, 一般に I 型アレルギーに分 類されるものが多い，その機序は，アレルゲンの侵入に よって生じた抗原特異的な IgEが，肥満細胞に結合し ている間に, 対応抗原が再び侵入することにより $\mathrm{IgE}$ が架橋されることが引き金となっている. その結果, 肥 満細胞からヒスタミンを代表とする種々の化学伝達物質 が放出され, 膨疹, 血管透過性六進, 血圧降下などの症 


\section{状が起きる.}

食品はこのようにアレルギーの原因となるが, 食品に はアレルギーを抑制したり軽隇する成分を含んでいるあ のがある ${ }^{1) ~ 3) . ~}$ 食品の抗アレルギー効果の簡便で正確な 評価法の開発は, アレルギーを予防し, 人の健康維持を 考える上できわめて重要な意味を持つ.

以前, 著者らは，マウスに mouse monoclonal antiDNP IgE 抗体 (Mm IgE) で感作後, ジニトロフェニル ヒト血清アルブミン (DNP-HSA) で惹起される受身アナ フィラキシー性血圧降下の抑制を指標とした抗アレル ギー性食品の評価法を報告した4). 本法は, 正常マウス に直接 $\mathrm{Mm} \mathrm{IgE}$ を投与することで生体内での抗体産生 期間が省略することができ, 讯速にアナフィラキシー反 応を誘発することができる，また，著者らは，抗原で能 動的に感作したマウスに同一抗原を腹壁に注射すること によって, 腹壁上に生じる血管透過性の六進度を指標と して評価できる局所アナフィラキシー反応の誘発法 （AW 法）を報告した ${ }^{5)}$. AW 法は, 簡便に, 高感度に, 再現性良くアナフィラキシー反応を評価することができ る.

著者らは今回，更に迅速なアッセイ法を確立すること を目的として, 受動感作の迅速性と, AW 法の簡便さ の利点を組み合わせた受身腹壁アナフィラキシー (passive abdominal wall anaphylaxis: PAA) 法を考案し, $\mathrm{PAA}$ 誘発の最適条件を確立したので報告する.

更に, PAAが H1 ブロッカーであるジフェンヒドラ ミンの経口前投与で, 用量依存的に再現性良く抑制され ることを証明した．この反応，すなわち受身腹壁アナ フィラキシー抑制 (PAA inhibition: PAAI) を指標とし て, 食品の抗アレルギー効果の探索試験に応用できるこ とを確認した。

PAA 法と類似の局所アナフィラキシー誘発方法に, 受身皮膚アナフィラキシー (passive cutaneous anaphylaxis: PCA) 反応 ${ }^{6)}$ が知られている. PCA 法では, マウス耳部を用いた場合, 耳介組織からの色素抽出, 吸 光度測定などが必須である7). また， ラット背部を用い たときは，あらかじめ，剪毛などの操作が必要となる。

これらは，一回の実験で多量の動物を使用するときには 特に煩雑なものとなる. PAA 法は, PCA 法と比較し て, 上述のような欠点を補うことができるという利点が ある。

\section{実験方法}

\section{1. 試}

Mouse IgE は, monoclonal anti-DNP IgE 抗体 (Mm IgE, H1 DNP-と-26.82) を用いた ${ }^{8)}$.

ジニトロフェニルヒト血清アルブミン (DNP-HSA) は, シグマ社より購入した（アルブミン 1 分子当たり, 30〜40 個のジニトロフェニル基を含有). ジフェンヒ ドラミン塩酸塩はナカライテスク社より購入した.

\section{2. 試料}

食品試料（ウーロン茶葉, にんにく, にら, しそ, だ いこん）は，すべて市販品をコープ浜甲子園店より購入 した.

\section{3. 実験動物}

$\mathrm{ddY}$ 系雄性 マウス 5 週齢(日本 $\operatorname{SLC}($ 株)) を用い た. 固形飼料 (CE-2, 日本クレア(株)) 及び水を自由に 与えて, $24 \pm 1^{\circ} \mathrm{C}$, 湿度 $55 \pm 5 \%$ で飼育した。

\section{4. 試料調製}

にんにく,にら,しそ,だいこんは, 可食部 $4.0 \mathrm{~g}$ に, $35.0 \mathrm{~mL}$ の精製水を加えフードミルで磨砕後, 精 製水で全量を $40.0 \mathrm{~mL}$ とした．続いて遠心分離 $(3,000$ $\left.\mathrm{rpm}, 10 \mathrm{~min}, 0^{\circ} \mathrm{C}\right)$ した上清を食品試料溶液とした。 ま た, ウーロン茶葉は 10 倍量の沸騰精製水で 10 分間抽 出し, 万過したものを食品試料溶液とした。

\section{PAA 法}

正常マウスに Mm IgE を投与することで, 受動的に 感作を行った. 感作成立後, 片岡らの操作手順 ${ }^{5}$ に従っ て $1 \%$ エバンスブルー溶液を静脈内注射し, 続けて腹 壁に DNP-HSA を注射 $(50 \mu \mathrm{L} / \mathrm{site})$ することにより PAA を誘発した.

PAAの評価は, 腹壁上に出現した色素斑の直径 $(x \mathrm{~mm})$ 加ら定義される血管透過性值 (Vascular Permeability Value: VPV) により行った $(\mathrm{VPV}=0, x<1.5$; $\mathrm{VPV}=25,1.5 \leqq x<4.5 ; \mathrm{VPV}=50,4.5 \leqq x<7.5 ; \mathrm{VPV}=$ $75,7.5 \leqq x<12.5 ; \mathrm{VPV}=100,12.5 \leqq x)^{5}$.

\section{統計処 理}

VPV は平均值士標準誤差で示した. また, 検査群と 対照群の間で Fisherの PLSD テストにより有意差検定 をした。

\section{結果及び考察}

\section{PAA における Mm IgE 量の検討}

正常マウスに $0.01 \sim 10 \mu \mathrm{g} /$ mouse の Mm IgE で腹 腔内に受動感作をし，24 時間後に DNP-HSA $(2 \mathrm{mg}$ ) $\mathrm{mL})$ で誘発される腹壁上の VPV を Fig. 1 に示した. $\mathrm{VPV}$ は, Mm IgE 量に依存して増加し, $0.5 \mu \mathrm{g} /$ mouse 以上の $\mathrm{Mm} \mathrm{IgE}$ で有意な PAA が誘発されるこ とが確認された。

Leng ら ${ }^{9)}$ により報告されているラットの背部を用い た PCA 反応では, $27 \mathrm{mg} / \mathrm{kg}$ の anti-DNP IgE（静脈 内投与）を使用している. この PCA 反応と比較して著 者らの提案した PAA 反応は非常に高感度な方法である (約 $0.02 \mathrm{mg} / \mathrm{kg}$, 腹腔内投与).

また, Fig. 1 は $0.5 \mu \mathrm{g} /$ mouse より $5 \mu \mathrm{g} /$ mouse の 抗体量の方が, より安定したアナフィラキシーを誘発で きることを示している.

血圧降下を指標とした場合，十分なアナフィラキシー を誘発するには, $10 \mu \mathrm{g} /$ mouse の投与量 ${ }^{4)}$ が必要で あったが, PAA 法ではその $1 / 2$ 量で確実に誘発するこ 


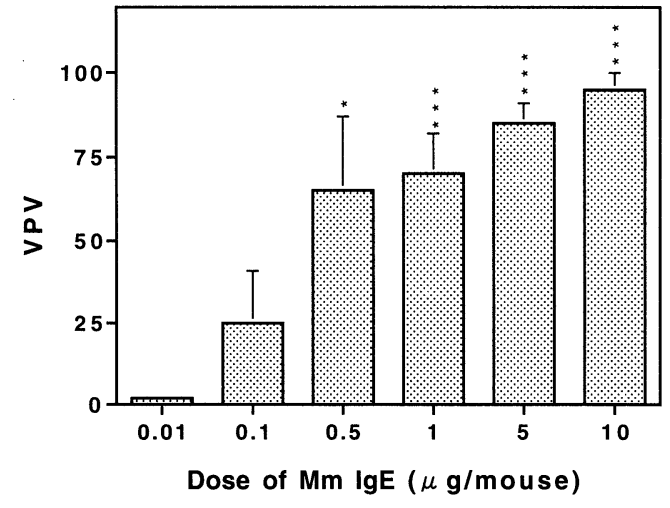

Fig. 1. Dose response of mouse monoclonal anti-DNP $\operatorname{lgE}$ antibody (Mm $\mathrm{IgE})$ on passive abdominal wall anaphylaxis (PAA)

Normal mice were passively sensitized intraperitoneally with different doses of $\mathrm{Mm}$ IgE, and 24 hours later, challenged with dinitrophenyl human serum albu$\min (2 \mathrm{mg} / \mathrm{mL}, 100 \mu \mathrm{g} / 50 \mu \mathrm{L} / \mathrm{site})$ on the abdominal wall. Each VPV (vascular permeability value) represents the mean士 S.E. for 5 mice. VPVs were defined as follows by the diameter $(x \mathrm{~mm})$ of the dyed area. $(\mathrm{VPV}=0, x<1.5 ; \mathrm{VPV}=25$, $1.5 \leqq x<4.5 ; \mathrm{VPV}=50,4.5 \leqq x<7.5 ; \mathrm{VPV}=$ $75, \quad 7.5 \leqq x<12.5 ; \quad \mathrm{VPV}=100, \quad 12.5 \leqq x)$ Statistical estimations were performed by analysis of variance, followed by Fisher's PLSD test. Asterisks indicate significant differences from the nonsensitized control group $(* * * p<0.001$, $* p<0.05)$.

\section{とが可能であった.}

\section{PAA における Mm IgE の投与部位の検討}

$1 \mu \mathrm{g}$ と $5 \mu \mathrm{g} /$ mouse の Mm IgE を用いて，腹腔内と 静脈内感作の違いによる VPV の影響を比較した。惹起 は 1 と同様に, 24 時間後に DNP-HSA $(2 \mathrm{mg} / \mathrm{mL})$ で 行った (Fig. 2).

その結果, 腹腔内投与の方が静脈内投与より高い VPVが得られた.これは, 血圧降下を指標とした場合 と同様であった。

\section{3. 若起における DNP-HSA 濃度の検討}

Fig. 3 に示すように $5 \mu \mathrm{g} /$ mouse の Mm IgE で感作 したマウスを用いて, 惹起における DNP-HSA 濃度の 影響を検討した. その結果, DNP-HSA は, $0.02 \mathrm{mg} /$ $\mathrm{mL}$ で誘発可能であり, 更に, 再現性良く十分な VPV を得るためには $0.2 \mathrm{mg} / \mathrm{mL}$ の DNP-HSA 量が適してい た $(10 \mu \mathrm{g} / 50 \mu \mathrm{L} / \mathrm{site})$.

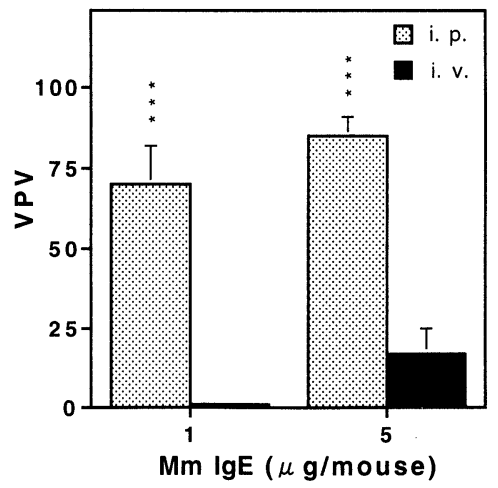

Fig. 2. Comparison of the administration routes and doses of mouse monoclonal anti-DNP IgE antibody (Mm IgE) on PAA

Normal mice received $\mathrm{Mm} \mathrm{IgE} \mathrm{of} 1 \mu \mathrm{g}$ or $5 \mu \mathrm{g}$, either intraperitoneally or intravenously, were challenged 24 hours later with dinitrophenyl human serum albumin $(2 \mathrm{mg} / \mathrm{mL}, 100 \mu \mathrm{g} / 50 \mu \mathrm{L} / \mathrm{site})$ on the abdominal wall. Each VPV (vascular permeability value) represents the mean \pm S.E. for $3 \sim 5$ mice. Statistical analyses were as in Fig. $1(* * * p<0.001)$.

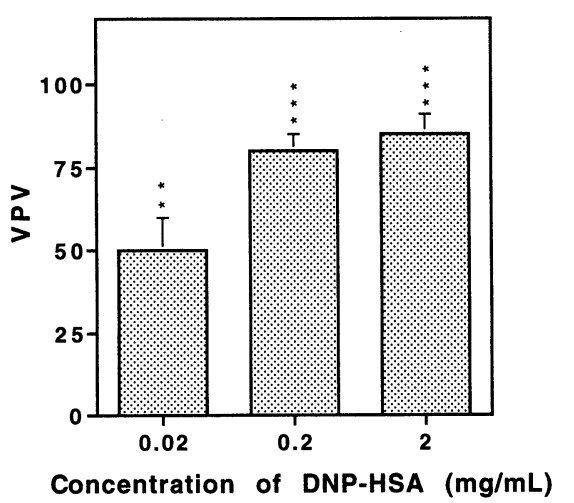

Fig. 3. Dose response of dinitrophenyl human serum albumin (DNP-HSA) on PAA

Normal mice were intraperitoneally sensitized with mouse monoclonal antiDNP IgE antibody (Mm IgE) of $5 \mu \mathrm{g} /$ mouse, 24 hours later, challenged with different concentrations of DNP-HSA on the abdominal wall. Each VPV (vascular permeability value) represents the mean \pm S.E. for $4 \sim 5$ mice. Statistical analyses were as in Fig. $1\left(* * *_{p}<0.001, *^{*} p<\right.$ 0.005).

このことから，DNP-HSA の投与量は血圧降下を指標 とした場合 ${ }^{4)}$ と比較して $1 / 10$ 量であり, PAA 法は高感 
度にアナフィラキシーを誘発できることが明確となっ た.

\section{4. 受動感作における誘発期間の検討}

Mm IgE ( $5 \mu \mathrm{g} /$ mouse $)$ の腹腔内投与後, 経時的に惹 起 $(0.2 \mathrm{mg} / \mathrm{mL}-\mathrm{DNP}-H S A, 10 \mu \mathrm{g} / 50 \mu \mathrm{L} / \mathrm{site})$ を行っ て得られた VPV の変化を，Fig. 4 に示した.この結果 より, PAA は受動感作後, 1 日目から 4 日目が最も高 感度であることが確認できた.この受動感作における誘 発期間は, Leng ら ${ }^{9)} ら$ らット背部 PCA 反応におけ る結果と類似するあのであった.

一方, 能動感作の場合には, 7 日目から 21 日目の長 期間にわたり誘発が可能であり ${ }^{5)}$, 受動感作とは大きく 異なっていた．この差の原因は, 受動感作では一回限り の $\operatorname{IgE}$ 投与であるが, 能動感作ではサイトカイン類の 刺激などが持続する期間中, IgE が産生, 供給されるこ とによると思われる.

\section{5. ジフェンヒドラミンによる PAA の抑制}

Mm IgE ( $5 \mu \mathrm{g} / \mathrm{mouse})$ を腹腔内投与して受身感作し たマウスに, 若起の 1 時間前に $\mathrm{H} 1$ ブロッカーであるジ

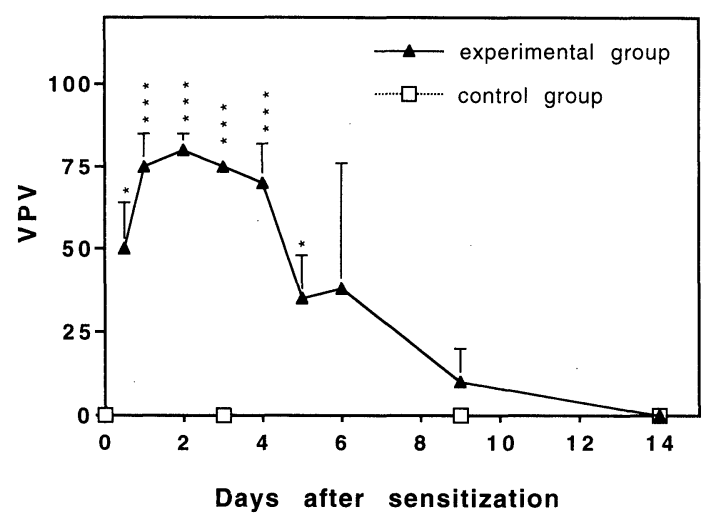

Fig. 4. Time course of PAA

Normal mice were sensitized with mouse monoclonal anti-DNP IgE antibody (Mm $\operatorname{IgE}) \quad(5 \mu \mathrm{g} /$ mouse) intraperitoneally, challenged with dinitrophenyl human serum albumin $(0.2 \mathrm{mg} / \mathrm{mL}, 10$ $\mu \mathrm{g} / 50 \mu \mathrm{L} / \mathrm{site})$ on the abdominal wall at the indicated days after sensitization. Mice in the control group were not sensitized, but were maintained and challenged under the same conditions as the experimental group. Each VPV (vascular permeability value) represents the mean \pm S.E. for $3 \sim 5$ mice. Statistical analyses were as in Fig. 1. Asterisks indicate significant differences from the control group of day $0\left(* * * p<0.001, *_{p}<\right.$ 0.05).
フェンヒドラミンを経口投与し, PAA の抑制 (PAA inhibition: PAAI) を検討した (Fig. 5).

その結果，血圧降下を指標とした場合と同様に， VPV はジフェンヒドラミンの経口前投与により用量依 存的に抑制された. このことから，PAAI を指標とする ことで，血圧降下の抑制を指標にするよりす，簡便に， 高感度に I 型アレルギーに対する食品の抗アレルギー効 果, 薬物の探索に利用できることが示唆された.

抗アレルギー性物質の探索に受動感作を用いる利点 は，能動感作のように抗原投与後マウス体内での抗体産 生期間を省略できるので, 受動感作後, 翌日には試験が 開始できる点にある. 欠点としてはメカニズム的に惹起 を抑制する成分の探索に限定される点にある. したがっ て, PAA 法の長所を活用して, 抗アレルギー性物質の 第一スクリーニングを迅速, 簡便, 高感度に行うことの できる PAAI 試験は有用であると思われる.

\section{6. 食品試料の PAAI 試験}

PAAI を抗アレルギー性食品の探索試験に応用した. 食品試料としては, 抗アレルギー作用があると言われて

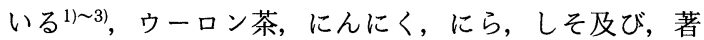

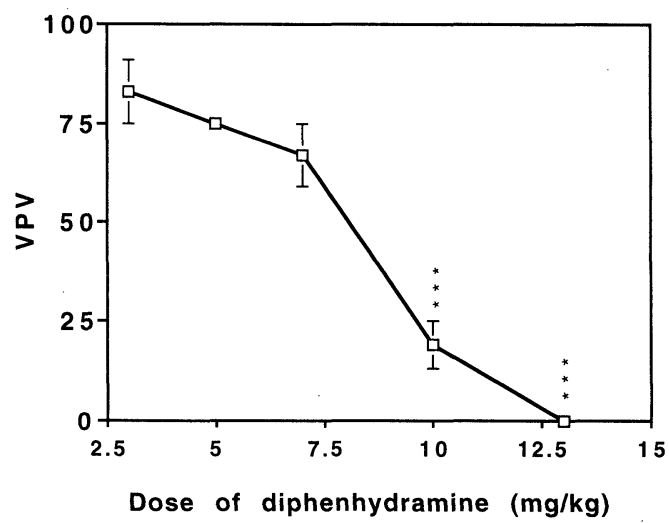

Fig. 5. Inhibition of passive abdominal anaphylaxis (PAAI) by diphenhydramine hydrochloride

Normal mice were intraperitoneally sensitized with mouse monoclonal antiDNP IgE antibody (Mm IgE) (5 $\mu \mathrm{g} /$ mouse). Twenty-four to 72 hours after sensitization, they were challenged with dinitrophenyl human serum albumin $(0.2 \mathrm{mg} / \mathrm{mL}, \quad 10 \mu \mathrm{g} / 50 \mu \mathrm{L} / \mathrm{site})$ on the abdominal wall. Different concentrations of diphenhydramine hydrochloride were administered orally an hour prior to challenge. Each VPV (vascular permeability value) represents the mean \pm S.E. for $3 \sim 4$ mice. Statistical analyses were as in Fig. $1(* * * p<0.001)$. 


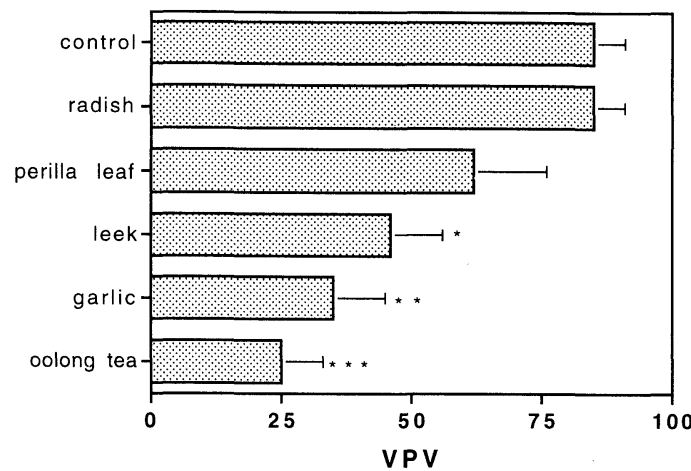

Fig. 6. Inhibition of passive abdominal anaphylaxis (PAAI) by foods

Normal mice were sensitized intraperitoneally with mouse monoclonal antiDNP IgE antibody (Mm IgE) of $5 \mu \mathrm{g} /$ mouse. Twenty-four to 72 hours after sensitization, they were challenged with dinitrophenyl human serum albumin $(0.2 \mathrm{mg} / \mathrm{mL}, \quad 10 \mu \mathrm{g} / 50 \mu \mathrm{L} / \mathrm{site})$ on the abdominal wall. The extract solutions of indicated foods of $0.2 \mathrm{~mL}$ were administered orally an hour prior to challenge. Each VPV (vascular permeability value) represents the mean \pm S.E. for $4 \sim$ 6 mice. Statistical analyses were as in Fig. 1. Asterisks indicate significant differences from the positive control group $\left(* * * p<0.001, * *_{p}<0.005, *_{p}<0.05\right)$.

者らの前回の報告 ${ }^{4)}$ で抗アレルギー作用が認められな かっただいこんの 5 品目を用いた，PAAI 試験には, 塩 崎 ${ }^{2)}$, 飛松ら ${ }^{4)}$ に従って食品試料溶液を惹起の 1 時間 前にゾンデを用いて経口投与 $(0.2 \mathrm{~mL} / \mathrm{mouse})$ した (Fig. 6).

その結果，ウーロン茶，にんにく，にらでは有意な PAAI が確認でき，だいこんではPAAI 効果を示さな かった．本法で用いたにんにく，にらの食品試料溶液 は, 前回 ${ }^{4)}$ の試料の $1 / 10$ 濃度であるので, より高感度 に食品の抗アレルギー効果の検査ができることが示唆さ れた. 一方，しそは, PAAI 効果を示す傾向が見られた あのの有意差を示すには至らなかった。これは, 試料の 濃度が低かったためか，しそ中の抗アレルギー性成分の 有効な抽出には熱水 ${ }^{3)}$ が必要であったためなどが考えら れる.このことから, 今後の食品試料の調製には複数の 抽出法, 濃度で行う必要があると思われる.

今回の予備実験結果から, PAAI を指標として食品の
抗アレルギー効果の簡便なスクリーニングが可能である と示唆された.

総括

（1） PAA（受身腹壁アナフィラキシー）法は正常マ ウスを Mm IgE で受動感作後, DNP-HSA を腹壁に注 射することにより，局所アナフィラキシーを再現性良く 誘発できる.

(2) $\mathrm{Mm} \mathrm{IgE}$ 量は, $0.5 \mu \mathrm{g} / \mathrm{mouse}$ 以上の腹腔内投与 で有意なPAA の誘発が可能であった. 更に確実でより 再現性良くPAA をおこすための抗体量は $5 \mu \mathrm{g} /$ mouse であった。

(3) Mm IgE (5 $\mu \mathrm{g} /$ mouse, i.p.) で感作したマウスは $0.2 \mathrm{mg} / \mathrm{mL}-\mathrm{DNP}-H S A, 10 \mu \mathrm{g} / 50 \mu \mathrm{L} / \mathrm{site}$ で再現性良 く十分な VPV を得ることができた.

(4) PAA は受動感作後, 1〜4 日間で高感度であっ た.

(5) PAA はH1 ブロッカーであるジフェンヒドラミ ンによって用量依存的に抑制された.このことから， PAAの抑制 (PAAI) 指標とした本法をI型アレル ギーに対する食品の抗アレルギー効果, 薬物探索のスク リーニングに応用できることが示唆された.

(6) 抗アレルギー作用があると言われているウーロ ン茶，にんにく，にらで有意な PAAI が認められた。

文献

1) 関谷敬三：ぶんせき 8, 656〜661 (1997).

2) 塩崎哲也, 杉山 清, 中里賢一, 竹尾忠一: 薬誌. 117, 448〜454 (1997).

3) 上田浩史, 山崎正利：和漢医薬学雑誌 $12,392 \sim 393$ (1995).

4) 飛松佳江, 片岡裕美, 平澤玲子, 井上朋美, 開原亜樹子, 小林由紀, 澤 典子, 扇間昌規, 伊藤誉志男, 高垣 裕: 日食化誌. 4, 17 20 (1997).

5) Kataoka, H., Tsuda, A., Tsuda Y., Baba, A., Yoshida, H., Hirasawa, R., Tobimatsu, Y., Nishiguchi, M., Semma, M., Ito, Y.: Biol. Pharm. Bull. 20, $714 \sim 716$ (1997).

6) 大内和雄: “生物薬科学実験講座, 炎症とアレルギー, 12, I-1” p. 96 (1993) 廣川書店.

7) Inagaki, N., Miura, T., Magaki, H., Ono, Y., Koda, A.: Int. Arch. Allergy Appl. Immunol. 87, 254 259 (1988).

8) Liu, F-T., Bohn, J. W., Ferry, E. L., Yamamoto, H., Molinaro, C. A., Sherman, L. A., Klinman, N. R., Katz, D. H.: J. Immunol. 124, 2,728 2,737 (1980).

9) Leng, W., Kuo, C. G., Qureshi, R., Jakschik, B. A.: ibid. 140, 2,361 2,368 (1988). 